Ракитина Наталья Эдуардовна

ведущий специалист учебно-методического управления Комсомольского-на-Амуре государственного технического университета

\section{ГОРОДСКИЕ РЕСУРСЫ И РИСКИ ДЕТСКИЙ ВЗГЛЯД (НА ПРИМЕРЕ ГОРОДОВ РОССИЙСКОГО ДАЛЬНЕГО ВОСТОКА)}

\section{Аннотация:}

В статье представлены результаты исследования детских представлений о ресурсах и рисках дальневосточных городов. Эмпирические данные собраны в городах-столицах четырех регионов Дальневосточного федерального округа. В ходе анкетирования детей 9-12 лет изучены их представления об имеющихся ресурсах и возможностях развития городской среды, выявлены детские страхи в городском пространстве.

\section{Ключевые слова:}

городская среда, городские ресурсы, риски, общественные пространства, мнение детей, детские городские страхи, детская инфраструктура, Дальний Восток.
Rakitina Natalya Eduardovna

Leading Specialist Curriculum and Instruction Department Komsomolsk-On-Amur State Technical University

\section{URBAN RESOURCES AND RISKS: CHILDREN'S VIEW (BY CASE STUDY OF THE RUSSIAN FAR EAST CITIES)}

This article presents the results of a research of children's views on resources and risks of the Far East cities. The empirical data are collected in the capitals of the four regions of the Far Eastern Federal District. While questioning the children at the age of 9-12 years old, the author studied their ideas of the available resources and opportunities of the urban environment development, as well as revealed the children's fears in city area.

Keywords:

urban environment, urban resources, risks, public spaces, children's opinion, children's city fears, children's infrastructure, Far East.

Интерес к детству, вписанному в городское пространство, зарубежные исследователи начали проявлять с середины прошлого века (К. Уорд, К. Линч). В 1990-2000-е гг. в социологических исследованиях детства произошел географический поворот, предпосылками которого стали исчезновение детей из публичных территорий, их невидимость на улицах современных городов (С. Холлоуэй, Дж. Квортруп, Дж. Валентайн, Х. Цайхер и др.). Хельга Цайхер замечает: «В наших городах дети играют в футбол в спортивных клубах чаще, чем на улицах, и забираются на разные игровые приспособления на детских площадках чаще, чем на деревья» [1].

Взрослые создают в городской среде «островки детства» - детские и подростковые клубы, рекреационно-развлекательные центры, спортивные и игровые площадки и т. п. Подобная «инсуляризация» [2] детства, с одной стороны, создает эффеккт защищенности детей от внешних рисков, с другой - приводит к ограничению их мобильности, затрудняет процесс формирования необходимых социальных навыков. Зачастую перемещение детей между такими «островками» осуществляется в сопровождении взрослых, иногда с использованием личного автомобиля.

Специфика российских дальневосточных городов заключается в превалировании в городских пространствах природных ресурсов над социальными. Серьезное разрушение социальной инфраструктуры города, в том числе детской, произошло в 1990-е гг. из-за смены собственников, отсутствия фринансирования, заброшенности, вандализма местных жителей и т. д. [3]. Открываемые в городах детские развлекательные центры и парки аттракционов относятся к группе высокопороговых учреждений, соответственно, не все дети могут регулярно их посещать. В таких условиях задачи организации досугового времени детей выполняют открытые общественные пространства, объекты природы.

В свете изучения фракторов внешнего и внутреннего неравенства детства риски и ресурсы выступают главными слагаемыми социального статуса детства, где риски обозначают полярные точки соприкосновения страт, а ресурсы - это актуальные возможности, активы для социализации в условиях современного города. С целью выявления городских ресурсов и рисков было проведено анкетирование детей.

Генеральная совокупность представлена детьми в возрасте 9-12 лет, проживающими в региональных центрах четырех субъектов ДВФО. Выборка организована пропорционально численности детей данной возрастной группы в четырех городах. Всего в опросе приняли участие 383 ребенка жители городов Владивостока (168 чел.), Хабаровска (125), Благовещенска (74), Биробиджана (16 чел.). 9-12 лет - это, с одной стороны, возраст, благоприятный для включения в социологическое исследование, а с другой - период активного освоения ребенком городского пространства. 
В настоящей работе анализируются ответы детей на три вопроса анкеты: «Что тебе нравится в своем городе?», «Что бы ты хотел изменить в своем городе?», «Когда ты на улице один, что тебя беспокоит?». В таблице 1 представлена картина, сложившаяся из ответов респондентов на первый вопрос.

Таблица 1 - Распределение ответов на вопрос: «Что тебе нравится в своем городе?»

\begin{tabular}{|l|c|c|c|c|c|c|c|c|}
\hline \multicolumn{1}{|c|}{ Варианты ответа } & \multicolumn{2}{|c|}{ Биробиджан } & \multicolumn{2}{|c|}{ Благовещенск } & \multicolumn{2}{|c|}{ Владивосток } & \multicolumn{2}{|c|}{ Хабаровск } \\
\cline { 2 - 10 } & $\%$ & ранг & $\%$ & ранг & $\%$ & ранг & $\%$ & ранг \\
\hline $\begin{array}{l}\text { Природные объекты: деревья, река, } \\
\text { море, поляны }\end{array}$ & 5 & $\mathrm{~V}$ & 5 & $\mathrm{~V}$ & 27 & $\mathrm{II}$ & 8 & $\mathrm{~V}$ \\
\hline $\begin{array}{l}\text { Исторические места: площади, музеи, } \\
\text { памятники }\end{array}$ & 9 & $\mathrm{IV}$ & 9 & $\mathrm{III}$ & 5 & $\mathrm{~V}$ & 8 & $\mathrm{VI}$ \\
\hline $\begin{array}{l}\text { Общественные пространства: парки, } \\
\text { скверы, площади, набережные }\end{array}$ & 47 & $\mathrm{I}$ & 50 & $\mathrm{I}$ & 42 & $\mathrm{I}$ & 38 & $\mathrm{I}$ \\
\hline $\begin{array}{l}\text { Объекты детской инфраструктуры: } \\
\text { клубы, секции }\end{array}$ & 12 & $\mathrm{III}$ & 9 & $\mathrm{IV}$ & 8 & $\mathrm{IV}$ & 9 & $\mathrm{IV}$ \\
\hline $\begin{array}{l}\text { Культурно-досуговые и развлекатель- } \\
\text { ные учреждения, центры }\end{array}$ & 18 & $\mathrm{II}$ & 22 & $\mathrm{II}$ & 13 & $\mathrm{III}$ & 19 & $\mathrm{II}$ \\
\hline Двор, детские площадки & 3 & $\mathrm{VII}$ & 1 & $\mathrm{VII}$ & 3 & $\mathrm{VI}$ & 14 & $\mathrm{III}$ \\
\hline Другое & 6 & $\mathrm{VI}$ & 4 & $\mathrm{VI}$ & 2 & $\mathrm{VII}$ & 4 & $\mathrm{VII}$ \\
\hline
\end{tabular}

На основании данных таблицы 1 выделена группа ответов детей, касающихся городской инфраструктуры. Дети говорят, что им нравятся театры и хорошие кинотеатры, общеобразовательные учреждения, где они учатся, парковые зоны, магазины и игровые площадки, стадионы, филармонии, дворцы культуры и другие культурно-досуговые учреждения. При этом необходимо отметить появление учреждений нового типа - развивающих и развлекательных центров, компьютерных клубов. Первые 2-3 ранга определяют смысловое ядро городских рисков и ресурсов, поэтому их содержание, как правило, повторяется в четырех выбранных городах.

Популярные городские места в ответах детей представлены преимущественно набережными, центральными площадями городов, пешеходными улицами, парками, скверами. Респондентам нравятся природные водные объекты: море, реки, пейзажи, мосты, набережные, маяки, сопки.

Дополняют картину городских ресурсов ответы на второй вопрос о том, как детям хотелось бы изменить свой город (табл. 2).

Таблица 2 - Распределение ответов на вопрос: «Что бы ты хотел изменить в своем городе?»

\begin{tabular}{|c|c|c|c|c|c|c|c|c|}
\hline \multirow{2}{*}{ Варианты ответа } & \multicolumn{2}{|c|}{ Биробиджан } & \multicolumn{2}{|c|}{ Благовещенск } & \multicolumn{2}{|c|}{ Владивосток } & \multicolumn{2}{|c|}{ Хабаровск } \\
\hline & $\%$ & ранг & $\%$ & ранг & $\%$ & ранг & $\%$ & ранг \\
\hline Улучшить экологию & 2 & VIII & 2 & IX & 11 & IV & 9 & $\mathrm{~V}$ \\
\hline Сделать улицы чище & 2 & IX & 7 & $\mathrm{~V}$ & 24 & II & 5 & $\mathrm{VI}$ \\
\hline $\begin{array}{l}\text { Сделать безопасными прогулки на } \\
\text { улице }\end{array}$ & 5 & VII & 5 & VII & 5 & VI & 12 & II \\
\hline $\begin{array}{l}\text { Открыть новые детские развлека- } \\
\text { тельные центры }\end{array}$ & 18 & II & 12 & II & 15 & III & 12 & III \\
\hline $\begin{array}{l}\text { Обновить, отремонтировать суще- } \\
\text { ствующие площадки, центры }\end{array}$ & 38 & I & 46 & 1 & 32 & I & 40 & I \\
\hline Улучшить взаимоотношения жителей & 7 & $\mathrm{~V}$ & 9 & III & 4 & VII & 10 & IV \\
\hline $\begin{array}{l}\text { Увеличить число парков, скверов, } \\
\text { площадей, где можно гулять }\end{array}$ & 13 & III & 9 & IV & 0 & IX & 4 & VIII \\
\hline Отремонтировать или построить дороги & 9 & IV & 7 & VI & 6 & $\mathrm{~V}$ & 5 & VII \\
\hline Другое & 6 & VI & 3 & VIII & 3 & VIII & 3 & IX \\
\hline
\end{tabular}

Респонденты высказали пожелания о большем разнообразии объектов инфраструктуры для игры и спорта. Сюда относится увеличение числа детских и спортивных площадок, современных аттракционов, открытие аквапарков, океанариумов. К необходимым местам для проведения досуга дети отнесли территории в городе, оборудованные треками для обучения езде на трюковых велосипедах, самокатах и скейтбордах. Среди других ответов: «удобные и комфортные автобусы», «ровные дороги», «бесплатные кружки», «чтобы не было преступлений», «чтобы было много добрых и счастливых детей», «больше парковок», «отремонтировать здания», «устроить приют для бездомных животных».

Изучение детских представлений позволило обозначить две линии изменений - благоустройство города (чистота на улицах, ремонт дорог, дополнительные парковки, озеленение общественных пространств) и создание детских зон (индустрия детских развлечений). 
Городские риски, обозначенные детьми, принявшими участие в исследовании (табл. 3), вызваны автомобилистами, бездомными собаками, людьми в состоянии опьянения.

\section{Таблица 3 - Распределение ответов на вопрос:}

«Когда ты на улице один, что тебя беспокоит?» (детские страхи)

\begin{tabular}{|l|c|c|c|c|c|c|c|c|}
\hline \multicolumn{2}{|c|}{ Варианты ответа } & \multicolumn{3}{c|}{ Биробиджан Благовещенск } & \multicolumn{2}{c|}{ Владивосток } & \multicolumn{2}{c|}{ Хабаровск } \\
\cline { 2 - 10 } & $\%$ & ранг & $\%$ & ранг & $\%$ & ранг & $\%$ & ранг \\
\hline Транспортное движение & 6 & $\mathrm{~V}$ & 7 & $\mathrm{~V}$ & 11 & $\mathrm{VI}$ & 13 & $\mathrm{IV}$ \\
\hline Страх потеряться & 6 & $\mathrm{VI}$ & 4 & $\mathrm{VI}$ & 7 & $\mathrm{VII}$ & 4 & $\mathrm{VII}$ \\
\hline Бездомные животные & 45 & $\mathrm{I}$ & 45 & $\mathrm{I}$ & 24 & $\mathrm{I}$ & 25 & $\mathrm{I}$ \\
\hline Люди без определенного места жительства & 11 & $\mathrm{III}$ & 10 & $\mathrm{IV}$ & 14 & $\mathrm{IV}$ & 23 & $\mathrm{II}$ \\
\hline Незнакомцы & 15 & $\mathrm{II}$ & 11 & $\mathrm{III}$ & 11 & $\mathrm{~V}$ & 14 & $\mathrm{III}$ \\
\hline Не бываю на улице один & 8 & $\mathrm{IV}$ & 15 & $\mathrm{II}$ & 17 & $\mathrm{II}$ & 8 & $\mathrm{VI}$ \\
\hline $\begin{array}{l}\text { Не знаю, что делать, если кто-то загово- } \\
\text { рит со мной }\end{array}$ & 5 & $\mathrm{VII}$ & 4 & $\mathrm{VII}$ & 15 & $\mathrm{III}$ & 12 & $\mathrm{~V}$ \\
\hline Другое & 4 & $\mathrm{VIII}$ & 4 & $\mathrm{VIII}$ & 1 & VIII & 1 & VIII \\
\hline
\end{tabular}

Анализ ответов обнаруживает, что больше всего детей пугают незнакомцы. Зарубежные исследователи именуют этот страх danger-stranger. При этом люди делятся просто на незнакомцев (часто в неадекватном состоянии - алкогольном, наркотическом опьянении) и на людей без определенного места жительства.

Также из данных таблицы 3 можно выделить довольно большую группу детей, практически не бывающих на улице в одиночестве, без сопровождения взрослых или друзей.

Таким образом, эмпирические данные, собранные в четырех дальневосточных городах региональных центрах, демонстрируют развитие городских пространств преимущественно в рекреационно-развлекательном направлении. Актуальным остается вопрос привлечения городских ресурсов для обеспечения безопасности и развития детей.

Рекомендации по развитию среды дальневосточных городов базируются на максимальном включении в процесс социализации детей природных объектов. Способами трансформации природных резервов могут стать природные детские площадки, зеленые зоны, включение элементов природной среды в общественные пространства. Дети постоянно используют в игре природные элементы (воду, песок, камни, ветки и др.). В то же время большие природные зоны могут быть использованы для занятий спортом, поскольку многие дети-дальневосточники за неимением серьезных учреждений дополнительного образования, в том числе в области культуры и искусства, проявляют установку на вовлечение в спортивные виды досуговой деятельности.

\section{Ссылки и примечания:}

1. Zeiher H. Shaping daily life in urban environments // Children in the city. Home, neighbourhood and community / ed. by P. Christensen, M. O'Brien. L. ; N. Y., 2003. P. 66.

2. Термин предложен X. Цайхлер.

3. Филипова А.Г. Общественные пространства и дети: Владивосток vs Хабаровск // Вестник Института социологии. 2016. № 1 (16). C. $28-41$.

\section{References:}

Filipova, AG 2016, 'Public space and children: Vladivostok vs Khabarovsk', Vestnik Instituta sotsiologii, no. 1 (16), pp. 2841, (in Russian).

Zeiher, H, Christensen, P \& O'Brien, M (eds.) 2003, 'Shaping daily life in urban environments', Children in the city. Home, neighbourhood and community, London, New York, p. 66, https://doi.org/10.4324/9780203167236. 